\title{
GWARANCJA ZATRUDNIENIA CZY DOCHÓD PODSTAWOWY?
}

\author{
PRAKTYKA TEORETYCZNA
}

W odpowiedzi na społeczny i gospodarczy kryzys w partiach i organizacjach lewicowych w Europie pojawiły się dwie, niewypróbowane w praktyce, strategie radykalnych reform: gwarancja zatrudnienia (GZ) i bezwarunkowy dochód podstawowy (BDP). Pierwszy z tych pomysłów zakłada wzięcie przez państwo odpowiedzialności za zapewnienie miejsc pracy tym, którzy nie mogą znaleźć jej w sektorze prywatnym. Państwo staje się tym samym „pracodawcą ostatniej instancji”. BDP oznacza zaś wypłacanie wszystkim obywatelom i obywatelkom pieniędzy wystarczających do zaspokojenia ich podstawowych potrzeb. Intelektualne źródła obu koncepcji sięgaja kilka wieków wstecz, jednak ożywiona debata na ich temat rozpoczęła się w latach osiemdziesiątych (w wypadku BDP) i dziewięćdziesiątych dwudziestego stulecia (w wypadku GZ).

Oba rozwiązania wiążą się z odmienną definicja głównego problemu właściwego współczesnemu kapitalizmowi (brak miejsc pracy versus brak środków lub niewynagradzanie wszystkich form pracy), różnym rozumieniem tego, co jest praca (praca zarobkowa versus szerokie ujęcie pracy), a także różnymi podstawami filozoficznymi i etycznymi. Najważniejsi przedstawiciele BDP wywodzą się z bardzo różnych nurtów ideologicznych i reprezentuja różne stanowiska teoretyczne: od neokeynesistów (James Meade, Joseph Stiglitz), przez marksistów analitycznych (Philippe Van Parijs, Erik O. Wright), neopolanyistę Guya Standinga i republikańską feministkę Carole Pateman, po republikańskich marksistów (Daniel Raventós, Antoni Domènech) i postoperaistów (Andrea Fumagalli, Michael Hardt, Antonio Negri, Carlo 
Vercellone). Z kolei niemal wszyscy zwolennicy GZ (L. Randall Wray, Philip Harvey, Pavlina Tcherneva, William Mitchell Mathew Forstater, Dimitri Papadimitriou) sa postkeynesistami, w większości reprezentującymi Nowoczesną Teorię Pieniężną (Modern Monetary Theory) i w wielu wypadkach związanymi z Instytutem Ekonomicznym Levy'ego' ${ }^{1}$. Ponieważ uważamy, że ten spór i to, która propozycja ostateczne zwycięży, zdefiniuje gospodarcza politykę lewicy w nadchodzących latach, zdecydowaliśmy się poświęcić ten numer „Praktyki Teoretycznej” porównaniu obu koncepcji.

Otwiera go tłumaczenie rozdziału wydanej w 2017 roku książki Guya Standinga Basic Income: And How We Can Make it Happen. Brytyjski ekonomista omawia w nich krytycznie rozwiązania alternatywne wobec BDP, które mają na celu przeciwdziałanie ubóstwu, rosnącym nierównościom, a także niepewności ekonomicznej i prekarności. Standing analizuje już stosowane rozwiązania: płacę minimalną, system ubezpieczeń społecznych, pomoc społeczną oparta na kryterium dochodowym, bony żywnościowe, system workfare, ulgi podatkowe i działalność charytatywna. Opisuje także dwie koncepcje: negatywnego podatku dochodowego oraz GZ, które (poza ograniczonymi czasowo i terytorialnie eksperymentami w wypadku tego pierwszego) nie zostały sprawdzone przez żadne z państw opiekuńczych. Wszystkie te rozwiązania poddaje testom na zgodność z pięcioma zasadami sprawiedliwości społecznej. Pyta zatem, czy zwiększają one bezpieczeństwo najmniej zabezpieczonych osób; czy nie są paternalistyczne względem wykluczonych; czy zwiększają zakres praw; czy nie są obciążające dla środowiska naturalnego oraz czy nie ograniczają możliwości wykonywania pracy w godny sposób. Wynikiem porównania jest stwierdzenie, że żadne z rozwiązań, poza dochodem podstawowym, nie realizuje wszystkich postulowanych przez Standinga zasad sprawiedliwości społecznej. GZ nie realizuje żadnej z nich, ponieważ zdaniem brytyjskiego ekonomisty jest paternalistyczna, zaprzecza wolności republikańskiej i nie może zapewnić godnej pracy. Wiele z tych tez znanych jest polskim czytelniczkom publikacji Standinga poświęconych prekariatowi; prezentowany tu przekład rozdziału ostatniej książki ekonomisty stanowi jednak systematyczne i klarowne podsumowanie argumentów, dlaczego BDP jest obecnie najlepszym znanym rozwiązaniem na kryzys współczesnego kapitalizmu i państwa dobrobytu.

Mariusz Baranowski i Bartosz Mika w artykule „Wielokryterialna ocena projektów bezwarunkowego dochodu podstawowego i gwarantowanego zatrudnienia” porównuja bezpośrednio koncepcje BDP i GZ pod względem problemów z finansowaniem, relacji z innymi świadczeniami społecznymi, wpływu na strukturę społeczną i wzorce kulturowe, a także politycznych możliwości wprowadzenia ich w życie. Zdaniem autorów niższe koszty, wpływ obecne systemy zabezpieczeń społecznych i stabilizujące konsekwencje

\footnotetext{
${ }^{1}$ Instytut Ekonomiczny Levy'ego jest nie powiązanym z żadną partią think tankiem zajmującym się polityką publiczną. Siedziba Instytutu mieści się w Bard College w miejscowości Annandale-on-Hudson w stanie Nowy Jork.
} 
makroekonomiczne, a także pewniejszy wpływ na podaż pracy daja pewna przewage GZ względem BDP. Natomiast ten drugi wypada nieznacznie lepiej pod względem zmniejszania nierówności społecznych i politycznych możliwości implementacji. Mika i Baranowski powołują się także na skuteczność polityki pełnego zatrudnienia za pomocą bezpośredniego tworzenia miejsc pracy w różnych krajach w przeszłości, powołując się m.in. na przykład Stanów Zjednoczonych czy Argentyny.

Empiryczny przykład na poziomie mikro opisuja Angelina Kussy i Félix Talego Vázquez w artykule „«Inny świat jest możliwy»: z gwarantowaną pracą czy z gwarantowanym dochodem? Przypadek Marinaledy". Na podstawie materiału etnograficznego zabranego przez autorów w hiszpańskiej wiosce Marinaleda pokazuja problemy wynikające z przyjęcia i kultywowania nowoczesnego, kapitalistycznego pojęcia pracy. W tym zakresie odrzucaja propozycję GZ jako pogłębiającą gloryfikację i centralne usytuowanie w życiu ludzi tak rozumianej pracy. Kładą nacisk na krytykę produktywizmu i nowoczesnego pojęcia pracy, którą uznaja za warunek emancypacji i głębokiej zmiany społecznej. Opowiadają się tym samym za BDP, które jest rozwiązaniem osłabiającym związek podmiotu z wąsko rozumianą praca, a jednocześnie narzędziem chroniącym zarówno przed wyzyskiem, jak i podporządkowaniem.

Również dla Zofii Łapniewskiej BDP może stanowić narzędzie przekształcenia obecnego porządku w kierunku gospodarki przyszłości opartej w większym stopniu na etyce troski. Takim narzędziem może być również w pewnej mierze GZ. W artykule „Etyka troski a gospodarka przyszłości” Łapniewska analizuje BDP i GZ z perspektywy feministycznej, wskazując na potencjalne zalety i wady obu rozwiązań. BDP jej zdaniem przyczyniłby się do wzmocnienia pozycji kobiet na rynku pracy. Zapewnienie realizacji podstawowych potrzeb za pomocą BDP byłoby najlepszym rozwiązaniem umożliwiającym cieszenie się z niematerialnych zasobów określających dobrostan społeczeństwa w gospodarce przyszłości, takich jak relacje z innymi ludźmi, wzajemna pomoc czy obcowanie z przyrodą.

Krytykę BDP z perspektywy Nowoczesnej Teorii Pieniężnej (NTP) przedstawia Pavlina R. Tcherneva w swoim artykule pt. „Jakie są względne zalety makroekonomiczne i wpływ na środowisko płynące $z$ bezpośredniego tworzenia miejsc pracy oraz dochodu podstawowego?”. Jej zdaniem jest on rozwiązaniem inflacjogennym i negatywnie oddziałującym na podaż pracy. Argumentuje, że GZ jest rozwiązaniem lepszym z perspektywy stabilizacji makroekonomicznej, a także jako narzędzie wspierania wielu celów ekologicznych. Tcherneva pozytywnie odnosi się do argentyńskiego programu bezpośredniego tworzenia miejsc pracy Jefes y Jefas de Hogar, a także opowiada się za propozycją dochodu partycypacyjnego, którą przedstawia jako potencjalny kompromis między zwolenniczkami BDP i GZ.

W komentarzu tłumacza do artykułu Tchernevy, Maciej Szlinder podaje w wątpliwość argumenty krytyczne amerykańskiej ekonomistki względem BDP, pokazując problematyczność leżących u ich podstaw założeń ekonomicznych i antropologicznych. Szlinder krytycznie 
analizuje również konsekwencje polityczne wynikające z NTP, a także podważa koncepcje dochodu partycypacyjnego jako rozwiązania kompromisowego.

Część tematyczną numeru kończy recenzja wspomnianej już nowej książki Guya Standinga autorstwa Mikołaja Ratajczaka. Książka Standinga dzięki połączeniu wymiaru ekonomicznego i prawno-politycznego stanowi, zdaniem recenzenta, dobre wprowadzenie do idei BDP, które jednocześnie w wyczerpujący sposób opisuje szczegóły i problemy związane z procesem politycznym jego implementacji. Jak zauważa Ratajczak, koncepcja BDP skłania nas do przemyślenia fundamentalnych pojęć organizujących nasz sposób myślenia o polityce, ponieważ dotyka kluczowych kwestii obecnie panującego porządku społeczno-gospodarczego.

Numer uzupełnia recenzja Macieja Grodzickiego z polskiego tłumaczenia książki Marianny Mazzucato Przedsiębiorcze państwo oraz artykuł Damiana Winczewskiego Michale Kaleckim i problemie racjonalnej alokacji zasobów w socjalizmie. Grodzicki docenia zasługi włoskiej ekonomistki w okrywaniu innowacyjnego potencjału państw, dostrzegając jednocześnie na elementy problematyczne (niewystarczająco realistyczny sposób ujmowania technologii) i możliwości uzupełnień książki (takie jak szersze ujęcie kategorii pracy czy uwzględnienie procesualnego charakteru polityk publicznych).

Winczewski rekonstruuje poglądy Michała Kaleckiego i zestawia je z poglądami zwolenników alternatywnych modeli gospodarki socjalistycznej, a także obrońców kapitalizmu. Analizie poddane zostały różnice w sposobie kształtowania się cen, sposobach zarządzania gospodarką i roli klasy robotniczej w socjalizmie i kapitalizmie. Winczewski wskazuje, że głównym problemem socjalizmu jest demokratyzacja relacji między warstwą zarządzająca produkcją a klasą robotnicza.

Problemy wpływu państwa kapitalistycznego na innowacje technologiczne oraz sposobu zarządzania gospodarką socjalistyczną uzupełniają główną oś numeru, którą jest refleksja nad możliwościami wprowadzenia reform w państwach kapitalistycznych, które znacząco zmieniałyby ich charakter lub wręcz budowały podwaliny pod fundamentalną zmianę systemowa. Numer ten jest zatem zarówno próbą ewaluacji konkretnych propozycji radykalnych reform, oceną stojących u ich podłoża założeń i ich prawdopodobnych konsekwencji, jak i ćwiczeniem z wyobraźni politycznej. Liczymy zatem, że jego lektura przyda się w pobudzaniu myślenia i działania na rzecz budowania dróg w kierunku postępowej zmiany społecznej, a także stworzy okazję do ożywionych dyskusji i polemik co do przebiegu tych dróg. 
CytowANIE: Praktyka Teoretyczna. 2017. „Gwarancja zatrudnienia czy dochód podstawowy?”. Praktyka Teoretyczna 2(24): 8-12.

DOI: $10.14746 /$ prt.2017.2.0

AUTHOR: Theoretical Practice

TiTLE: Job Guarantee or Basic Income? 